University of Nebraska - Lincoln

DigitalCommons@University of Nebraska - Lincoln

$6-2013$

\title{
Potential oversummering and overwintering regions for the wheat stripe rust pathogen in the contiguous United States
}

Dipak Sharma-Poudyal

Washington State University

Xianming Chen

Washington State University, xianming@wsu.edu

Richard Alan Rupp

Washington State University

Follow this and additional works at: https://digitalcommons.unl.edu/usdaarsfacpub

Sharma-Poudyal, Dipak; Chen, Xianming; and Rupp, Richard Alan, "Potential oversummering and overwintering regions for the wheat stripe rust pathogen in the contiguous United States" (2013). Publications from USDA-ARS / UNL Faculty. 1236.

https://digitalcommons.unl.edu/usdaarsfacpub/1236

This Article is brought to you for free and open access by the U.S. Department of Agriculture: Agricultural Research Service, Lincoln, Nebraska at DigitalCommons@University of Nebraska - Lincoln. It has been accepted for inclusion in Publications from USDA-ARS / UNL Faculty by an authorized administrator of DigitalCommons@University of Nebraska - Lincoln. 


\title{
Potential oversummering and overwintering regions for the wheat stripe rust pathogen in the contiguous United States
}

\author{
Dipak Sharma-Poudyal • Xianming Chen • \\ Richard Alan Rupp
}

This article is a U.S. government work, and is not subject to copyright in the United States.

Received: 20 January 2013 /Revised: 28 March 2013 / Accepted: 10 May 2013

(C) US Government 2013

\begin{abstract}
Epidemics of wheat stripe rust, caused by Puccinia striiformis f. sp. tritici (Pst), are more frequent in the regions where Pst can oversummer and overwinter. Regions for potential oversummering and overwintering of Pst were determined in the contiguous United States using a survival index (SI) ranging from 0 (most unfavorable) to 10 (most favorable) developed based on long-term weather data. The pathogen can survive in cool summer in the most regions north of latitude $40^{\circ} \mathrm{N}$, particularly Washington, Idaho, Montana, Oregon and California. Due to limiting high temperatures, it survives marginally during summer in Arkansas, Delaware, Georgia, Iowa, Illinois, Indiana, Kansas, Kentucky, Massachusetts, Missouri, Ohio, Oklahoma, Rhode Island and Texas. Similarly, unfavorable hot summer restricts summer survival of the pathogen in the most regions south of $40^{\circ} \mathrm{N}$ except for highlands in the Rocky or Appalachian Mountains. Warm winters favor fungal survival in most regions south of $40^{\circ} \mathrm{N}$ and the Pacific Coast, including Alabama, Arkansas, Arizona, California, Florida, Georgia, Idaho, Louisiana, Mississippi, New Mexico, Nevada, Oregon, South Carolina, Texas and Washington. Severe winters do not allow survival in most regions north of $40^{\circ} \mathrm{N}$ and east of the Rocky Mountains, whereas less severe winter in Delaware, Illinois, Indiana, Kansas, Kentucky, Massachusetts, Maryland, Michigan,
\end{abstract}

D. Sharma-Poudyal $\cdot X$. Chen $(\bowtie)$

Department of Plant Pathology, Washington State University,

Pullman, WA 99164-6430, USA

e-mail: xianming@wsu.edu

X. Chen

Wheat Genetics, Quality, Physiology, and Disease Research Unit, US Department of Agriculture-Agricultural Research Service, Pullman, WA 99164-6430, USA

R. A. Rupp

Department of Crop and Soil Sciences, Washington State

University, Pullman, WA 99164-6420, USA
Missouri, North Carolina, New Jersey, New York, Ohio, Oklahoma, Pennsylvania, Rhode Island, Tennessee, Utah and Virginia permits marginal survival of Pst. Most wheatgrowing regions have climatic suitability for either oversummering or overwintering. Both oversummering and overwintering can occur in the Pacific Northwest (Idaho, Oregon and Washington), Arizona, California, North Carolina, New Mexico, Pennsylvania, Virginia and West Virginia. These regions may provide primary inoculum for stripe rust epidemics in their own and surrounding regions.

Keywords GIS · Oversummering · Overwintering · Pathogen survival · Puccinia striiformis · Stripe rust . Yellow rust

\section{Introduction}

Puccinia striiformis Westend. f. sp. tritici Erikss. (Pst) causes a major wheat disease - stripe rust of wheat - worldwide including in the United States (US) (Stubbs 1985; Chen 2005). The disease often causes over $50 \%$ yield losses at a local or farm level (Doodson et al. 1964; Murray et al. 1994). Yield loss may reach $100 \%$ on highly susceptible cultivars under severe disease conditions (Chen 2005). The highest statewide wheat yield loss recorded was $25 \%$ in California in 2003 (http://www.ars.usda.gov/Main/docs.htm? docid=10123). During 2000-2010, the most severe stripe rust epidemics occurred in 2010, causing $5.8 \%(2,364,125 \mathrm{t})$ and $1.4 \%(242,316 \mathrm{t})$ yield loss of the US total winter and spring wheat production, respectively (http://www.ars.usda.gov/ Main/docs.htm?docid=10123), even after the widespread application of fungicides to control the disease (Sharma-Poudyal and Chen 2011).

Historically, wheat stripe rust has been more destructive in states west of the Rocky Mountains, especially 
Washington, Idaho, Oregon and California since late 1950s; and has become more frequently destructive in states east of the Rocky Mountains since 2000 (Chen 2005). Stripe rust has caused significant yield loss of winter and spring wheat in most of major wheat-growing states (http://www.ars.usda.gov/ Main/docs.htm?docid=10123). Frequent stripe rust epidemics are common in areas or neighboring areas where weather favors oversummering and overwintering of the pathogen. Under suitable climate conditions, Pst has the potential to overseason on about 320 species of grasses from 50 genera in addition to its primary host wheat (Burleigh 1965; Hassebrauk 1965; Tollenaar and Houston 1967; Tu 1967; Stubbs 1985). Therefore, overseasoning dormant mycelia/ uredia of Pst can produce disease foci and cause an epidemic as the conducive season progresses (Burleigh 1965; Tollenaar and Houston 1967; Tu 1967; Shaner and Powelson 1973; Line 2002). Stripe rust often first appears in foci primarily because overseasoning pathogen populations are restricted to patches of its hosts (Line 2002). Stripe rust is a polycyclic disease and the pathogen produces urediniospores in multiple cycles. Urediniospores can spread from the origin as aerial spores (Zadoks 1961). Wind facilitates long-distance movement of urediniospores causing local, regional and interregional epidemics (Brown and Hovmøller 2002; Wang et al. 2010). In addition, mutated or recombined Pst isolates can survive throughout the year in summer and winter survival areas and thus these areas are often hotspots for detection of new and more races than other areas (Line and Qayoum 1992; Li and Zeng 2002; Chen et al. 2010). Identification of survival hot spots and adaptation of integrated disease management strategies in pathogen survival areas can reduce inoculum pressure and increase effective duration of resistance genes in other epidemiological regions. Therefore, pathogen overseasoning areas have large epidemic consequences with its importance in local, regional and interregional scale for the disease prediction and management.

Previously the US has been classified into seven stripe rust epidemiological regions based on geographic barriers; prevailing wind, temperature, and precipitation; classes of wheat; cropping methods; and Pst races (Line and Qayoum 1992; Line 2002). Chen et al. (2010) further subdivided the regions into 12 stripe rust epidemiological regions also considering epidemic frequencies and levels. Climatic suitability for potential survival of $P s t$ in these regions is yet to be determined, especially in regions east of the Rocky Mountains. Pathogen oversummering and overwintering areas have been studied and identified in some areas of California, Montana, Idaho, Oregon and Washington (Sharp and Hehn 1963; Burleigh 1965; Tollenaar and Houston 1967; Tu 1967; Shaner and Powelson 1971; Shaner and Powelson 1973). These studies have explained the role of climatic conditions on the biology of Pst and its survival. Studies conducted outside the US have added valuable information regarding weather conditions favorable for active and dormant survival of Pst (Georgievskaja 1966; Rapilly 1979; Dennis and Brown 1986; Dennis 1987a, b; Ellison and Murray 1992; Li and Zeng 2002). Weather variables have been used to determine the potential oversummering and overwintering Pst regions in China using a geographical information system (Ma et al. 2005; Shi and Ma 2005). Thus, identified survival regions have been used to devise sustainable stripe rust management strategies in China (Kang et al. 2010). Although the previous studies have identified oversummering and overwintering areas, and weather variables favorable for Pst survival in a few western regions of the US, these variables have not been extrapolated to determine potential survival regions in the US. Therefore, the objectives of this study were to identify geographic regions within the contiguous US that are potentially suitable for Pst survival during summer and winter, and to identify areas that can serve as sources of inoculum for stripe rust epidemics.

\section{Materials and methods}

Study areas and data sources

The mainland US with 48 states was included in the study. A total of 445 weather stations were selected representing at least 1 weather station per $160 \mathrm{~km}$ (about 100 miles) in radius. Weather stations were chosen more intensely for areas with a varied topography and major wheat-growing areas. Climatic data from 1950 to 2007 and geographical information (longitude, latitude and elevation) of each location were obtained from the National Climatic Data Center (NCDC) (http://cdo.ncdc.noaa.gov/CDO/dataproduct). Dew point (DP) and snow depth data were obtained from PRISM data explorer (http://prismmap.nacse.org/nn/) and snow climatology (http://www.ncdc.noaa.gov/ussc/index.jsp), respectively. Relative humidity ( $\mathrm{RH}$ ) was calculated from temperature and DP using the August-Roche-Magnus approximation method (http://einstein.atmos.colostate.edu/ $\sim$ monoldy/Humidity.html).

Survival index

A survival index (SI) was developed from most unfavorable (0) to most favorable (10) for winter and summer based on climatic conditions for Pst published in the literature (Tables 1, 2) (Burleigh 1965; Sharp 1965; Tollenaar and Houston 1967; Tu 1967; Shaner and Powelson 1971; Rapilly 1979; Dennis 1987a, b; de Vallavieille-Pope et al. 1995; Li and Zeng 2002; Line 2002; Chen 2005). Temperature is an important factor influencing stripe rust 
Table 1 Climatic conditions used for estimation of potential summer survival indices of Puccinia strifformis f. sp. tritici. Max Maximum, MAT moving average temperature, Temp temperature, Min minimum, SI survival index

\begin{tabular}{|c|c|c|}
\hline \multicolumn{2}{|l|}{ Climatic parameter } & \multirow[t]{2}{*}{ SI $(0-10)$} \\
\hline \multicolumn{2}{|l|}{ Temperature $\left({ }^{\circ} \mathrm{C}\right)$} & \\
\hline Max30D-MAT (Max): description & 30-D Min: description & \\
\hline$\geq 38$ : Unfavorable for survival & Otherwise & 0 \\
\hline Otherwise & $>22$ : Unfavorable for survival & 0 \\
\hline 37-34: Dormant survival & 19-22: Putative upper marginal limit for infection & 1 \\
\hline 37-34: Dormant survival & 16-18: Marginally favorable for infection & 2 \\
\hline 37-34: Dormant survival & 14-15: Moderately favorable for infection & 3 \\
\hline 37-34: Dormant survival & 13-12: Favorable for infection & 4 \\
\hline 37-34: Dormant survival & $\leq 11$ : Highly Favorable for germination and infection & 5 \\
\hline$\leq 33$ : Active survival & 19-22: Putative upper marginal limit for infection & 2 \\
\hline$\leq 33$ : Active survival & 16-18: Marginally favorable for infection & 4 \\
\hline$\leq 33$ : Active survival & 14-15: Moderately favorable for infection & 6 \\
\hline$\leq 33$ : Active survival & 13-12: Favorable for infection & 8 \\
\hline$\leq 33$ : Active survival & 7-11: Highly Favorable for germination and infection & 10 \\
\hline \multicolumn{3}{|c|}{ Correction factors for temperature based survival index } \\
\hline \multicolumn{3}{|c|}{ Temperature and relative humidity: description } \\
\hline \multicolumn{2}{|c|}{30 days Min Temp $\geq 20{ }^{\circ} \mathrm{C}$ and relative humidity $\geq 65 \%$ : Unfavorable for survival } & 0 \\
\hline \multicolumn{3}{|c|}{ Dew point and Min temp, and Precipitation (mm): description } \\
\hline \multirow[t]{4}{*}{ Dew point $<$ Min temp } & $>30$ : Favorable for infection & No correction \\
\hline & 11-30: Moderately favorable for infection & -1 on Temp based SI \\
\hline & 6-10: Marginally favorable for infection & -2 on Temp based SI \\
\hline & $\leq 5$ : Unfavorable for infection & 0 \\
\hline \multirow[t]{3}{*}{ Dew point $\geq$ Min temp } & $>10$ : Favorable for infection & No correction \\
\hline & 6-10: Moderately favorable for infection & -1 on Temp based SI \\
\hline & $<5$ : Marginally favorable for infection & -2 on Temp based SI \\
\hline
\end{tabular}

development and its survival (Burleigh 1965; Dennis 1987a, b; Line 2002; Chen 2005). Therefore, SI was based primarily on temperature and corrected with RH, DP and rainfall. Initially, survival indices were estimated for selected locations in Washington, Oregon and Idaho, where the history of stripe rust epidemics is known. These calibrated survival indices were then extended to other locations.

\section{Summer survival index}

High temperatures during summer limit the survival of Pst (Tollenaar and Houston 1966, 1967; Tu 1967; Chen 2005). Constant high temperature has a greater detrimental effect on mycelia and uredinial survival than alternating high and low temperatures (Tu 1967; Dennis 1987a). A short exposure to extreme temperatures does not kill the pathogen and consequently disease develops (Chen 2005). Therefore, both maximum and minimum temperatures were used to estimate SI. Summer season was defined as June-September. Maximum and daily mean temperatures were calculated based on the daily maximum and minimum temperatures. Maximum moving average temperature (MAT) for 10, 20,
30 and 60 days based on daily maximum and mean temperatures were calculated as described by Sharma-Poudyal and Chen (2011). Similarly, a minimum temperature for the same MAT periods was computed from the daily minimum temperatures. These 10- to 60-day maximum MATs and minimum temperatures were used to determine the appropriate MAT period to estimate SI based on the climatic conditions described in Table 1. Survival indices obtained from the 30-day maximum MAT based on the daily maximum temperature [Max30D-MAT(Max)] and 30-day minimum (30D-Min) temperature for the same period had consistent and reasonable SI for selected PNW locations. Thus Max30D-MAT(Max) and 30D-Min were used as temperature conditions to estimate summer SI.

Max30D-MAT(Max) and 30D-Min temperatures were classified into three and six categories, respectively (Table 1). Max30D-MAT(Max) temperature parameter defines the lethal limit for the pathogen to survival $\left(\geq 38^{\circ} \mathrm{C}\right)$, dormant survival $\left(34-37^{\circ} \mathrm{C}\right)$ and active survival $\left(<33^{\circ} \mathrm{C}\right)$ as described by $\mathrm{Tu}(1967)$. Although Pst can tolerate $38^{\circ} \mathrm{C}$ peak temperature for a very short period of time (Georgievskaja 1966), the 10-day maximum temperature 
Table 2 Climatic conditions used for estimation of potential winter survival index of $P$. striiformis $\mathrm{f}$. sp. tritici

Climatic parameter

SI $(0-10)$

Temperature $\left({ }^{\circ} \mathrm{C}\right)$ and snow cover $(\mathrm{cm})$

Min30D-MAT(Min) and snow cover: Description

$\leq-11^{\circ} \mathrm{C}$ and $\geq 7.6 \mathrm{~cm}$ : lower limit for survival

$\leq-6{ }^{\circ} \mathrm{C}$ and $<7.6 \mathrm{~cm}$ : lower limit for survival

Otherwise

$\leq-2$ to $-10{ }^{\circ} \mathrm{C}$ and $\geq 7.6 \mathrm{~cm}$ or $\leq-2$ to $-5{ }^{\circ} \mathrm{C}$ and $<7.6 \mathrm{~cm}$ : Survive as dormant mycelium

$\geq-1$ to $11^{\circ} \mathrm{C}$ : Active survival

\begin{tabular}{|c|c|}
\hline \multicolumn{2}{|l|}{ 30-D Max: description } \\
\hline Otherwise & 0 \\
\hline Otherwise & 0 \\
\hline$\leq-5^{\circ} \mathrm{C}$ : Lower limit for germination and infection & 0 \\
\hline $\begin{array}{l}\leq-3 \text { to }-4{ }^{\circ} \mathrm{C} \text { : Putative lower marginal limit for } \\
\text { germination and infection }\end{array}$ & 1 \\
\hline $\begin{array}{l}\leq-2 \text { to }-1{ }^{\circ} \mathrm{C} \text { : Marginally favorable for infection and } \\
\text { infection }\end{array}$ & 2 \\
\hline $\begin{array}{l}0 \text { to } 1^{\circ} \mathrm{C} \text { : Moderately favorable for germination } \\
\text { infection }\end{array}$ & 3 \\
\hline 2 to $11^{\circ} \mathrm{C}$ : Favorable for germination and infection & 4 \\
\hline$\geq 12$ to $30^{\circ} \mathrm{C}$ : Favorable disease development & 5 \\
\hline $\begin{array}{l}\leq-3 \text { to }-4{ }^{\circ} \mathrm{C} \text { : Putative lower marginal limit for } \\
\text { germination and infection }\end{array}$ & 2 \\
\hline $\begin{array}{l}\leq-2 \text { to }-1{ }^{\circ} \mathrm{C} \text { : Marginally favorable for infection and } \\
\text { infection }\end{array}$ & 4 \\
\hline $\begin{array}{l}0 \text { to } 1{ }^{\circ} \mathrm{C} \text { : Moderately favorable for germination } \\
\text { infection }\end{array}$ & 6 \\
\hline 2 to $11{ }^{\circ} \mathrm{C}$ : Favorable for germination and infection & 8 \\
\hline$\geq 12$ to $30{ }^{\circ} \mathrm{C}$ : Favorable disease & \\
\hline
\end{tabular}

Correction factors ${ }^{\mathrm{a}}$

${ }^{a}$ Correction for temperature and relative humidity; and dew point, minimum temperature and precipitation was done as described in Table 1 . If minimum temperature is $\geq 12^{\circ} \mathrm{C}$ then SI calculation as described for summer SI in Table 1

$\geq 32.4{ }^{\circ} \mathrm{C}$ was found to be lethal for Pst survival (Tollenaar and Houston 1967). However, the pathogen can survive if the daily temperature range is large even if the maximum temperature is $32.4{ }^{\circ} \mathrm{C}$. Latent infection of Pst during the summer season with a maximum temperature of $36.6^{\circ} \mathrm{C}$ has been reported in Pullman, WA ( $\mathrm{Tu}$ 1967). Therefore, the Max30D-MAT(Max) $\geq 38{ }^{\circ} \mathrm{C}$ is considered as the lethal temperature regardless of daily temperature range. Temperatures above $33{ }^{\circ} \mathrm{C}$ stop sporulation (Rapilly 1979) and therefore daily maximum temperatures $\geq 34$ to $37{ }^{\circ} \mathrm{C}$ induce dormant survival of the pathogen. Relatively high temperatures during late summer favor dormant survival; Pst resumes active survival in the fall when temperature becomes low in Canada and the US Pacific Northwest (Line 2002). The mycelium in a leaf can survive up to 30 days when alternate high $\left(<30{ }^{\circ} \mathrm{C}\right)$ and low $\left(<18{ }^{\circ} \mathrm{C}\right)$ daily temperatures occur. These mycelium survival days are very close to survival days found when plants were subjected to lower temperatures ( $\mathrm{Tu}$ 1967), but the pathogen cannot survive at constant or mean temperatures above $22{ }^{\circ} \mathrm{C}$ for a 10-day period (Sharp 1965; Tollenaar and Houston 1967; Shaner and Powelson 1971; Li and Zeng 2002). Therefore, the pathogen does not survive when either Max30D-MAT(Max) is $\geq 38{ }^{\circ} \mathrm{C}$ for 30 days or minimum temperature is $>22{ }^{\circ} \mathrm{C}$. When the daily maximum temperature is not lethal for Pst, it can establish in plants and survive if the daily temperature range is high or the minimum temperature is favorable. In such conditions, minimum temperature plays a significant role in the survival of Pst. Therefore, the corresponding 30D-Min temperature during the hottest period was simultaneously integrated into the temperature parameter. 30D-Min temperatures were further classified into six classes based on suitability for Pst germination, infection and survival. Tu (1967) observed trace infection at $21.1{ }^{\circ} \mathrm{C}$ under controlled conditions. Therefore, temperatures from 19 to $22{ }^{\circ} \mathrm{C}$ are considered as a putative upper limit for marginal infection. Similarly, $16-18^{\circ} \mathrm{C}$ marginally favors infection if an extended wet period exists (Dennis 1987b). Infection was reported more at temperatures of $14-15^{\circ} \mathrm{C}$ compared to $16-18{ }^{\circ} \mathrm{C}$, but less than at $12-13{ }^{\circ} \mathrm{C}$ (Dennis 1987b; de Vallavieille-Pope et al. 1995). Temperatures of $14-15{ }^{\circ} \mathrm{C}$ and $12-13{ }^{\circ} \mathrm{C}$ were classified as moderately favorable and favorable for infection, respectively. The optimum temperature for germination is $7{ }^{\circ} \mathrm{C}$ and for infection is $7-11^{\circ} \mathrm{C}$. Therefore, temperatures ranged from 7 to $11^{\circ} \mathrm{C}$ are considered as highly favorable for germination and infection (Rapilly 1979; Dennis 1987b; de Vallavieille-Pope et al. 1995).

Temperature-based calculated SI was corrected with RH and minimum temperature. In general, temperature and $\mathrm{RH}$ influence spore longevity. For most fungi, the length of spore life, as measured by ability to germinate after various 
periods, decreases as temperature, conidial moisture content or RH increase (Hong et al. 1997). Hydrated rust urediniospores at higher RH lose spore longevity, germinability and infectivity compared to non-hydrated spores at lower RH even at the same temperature, whereas lower temperatures and decreasing RH increase longevity (Hong et al. 1997; Imbaby et al. 2005). Stripe rust urediniospores are sensitive to UV radiation and the lethal effect of radiation increases as water content in urediniospores increases or with relative high humidity (Maddison and Manners 1973). The relationship between RH and Pst viability does not appear to be simple. The fungal urediniospores mostly persist longer, but the chances of infection are reduced at lower humidity (Chen 2005; Smilanick and Mansour 2007). If a location had 30 days minimum temperature $\geq 20^{\circ} \mathrm{C}$ and $\mathrm{RH} \geq 65 \%$, then an assumption was made that $P$ st could not survive even as urediniospores and therefore the SI based on temperature was transformed to 0 .

Survival indices were further corrected based on DP, minimum temperature and amount of rainfall for the hottest month to address the free water or dew requirement for successful germination and infection. Requirement of different wetness periods for infection at different temperature ranges has been demonstrated in controlled conditions (Burleigh 1965; Dennis 1987b). Under field conditions, however, the relationships among the DP, ambient temperature and rainfall for the infection and survival are yet to be studied. Therefore, we used climate data of areas known historically for stripe rust epidemics: Mt. Vernon, Pullman, Lind and Walla Walla of Washington State. These areas were used to standardize the DP, minimum temperature and rainfall conditions for Pst survival (Table 1). When the DP is less than the minimum temperature, infection depends on the amount of rainfall. Rainfall greater than $30 \mathrm{~mm}$ during a 30-day period is considered favorable for infection. Similarly, rainfall from 11 to $30 \mathrm{~mm}$ was classified as moderately favorable and 6 to $10 \mathrm{~mm}$ as marginally favorable for infection. Rainfall equal or less than $5 \mathrm{~mm}$ evaporates quickly and is unfavorable for infection. Areas with low rainfall ( $<5 \mathrm{~mm}$ during a month) are like deserts with no or very little vegetation (Brouwer and Heibloem 1986). Although temperature may be favorable for survival of the rust pathogen in this region, availability of suitable hosts for Pst is very unlikely. Therefore, desert-like areas were transformed to unfavorable. But when a DP is equal or more than the minimum temperature, in addition to rainfall, dew present on leaves plays a significant role to provide necessary wet period for spore germination and infection. Dew periods often last for more than $3 \mathrm{~h}$ up to $12 \mathrm{~h}$ during the summer growing season and this range of dew duration frequently favors plant infection by obligate pathogens (Sutton 1988). Therefore, rainfall greater than $10 \mathrm{~mm}$ was considered as favorable, $6-10 \mathrm{~mm}$ moderately favorable, and $<5 \mathrm{~mm}$ marginally favorable for infection.
Winter survival index

The winter season was considered from November to February to cover any coldest period of the year. During the winter season, the minimum temperature is a limiting factor for Pst survival (Burleigh 1965). Urediniospores of Pst can germinate and infect hosts even in the presence of light (McCracken and Burleigh 1962). A winter SI for each location was calculated based on temperature and snow depth, temperature and RH, DP and amount of rainfall. In the presence of dew or free water, the maximum temperature during the day time may allow infection. Therefore, survival indices were estimated simultaneously based on minimum and maximum temperatures. Minimum MATs were calculated based on the daily minimum and mean temperatures. Minimum MATs for the 10-, 20-, 30- and 60-day periods were calculated. Similarly, maximum temperatures for corresponding MAT periods were computed based on the daily maximum temperatures. These periods of MATs along with snow depth and maximum temperature for these MATs were used to determine the appropriate MAT period to calculate the potential SI based on survival parameters developed in Table 2. A minimum snow cover of $7.6 \mathrm{~cm}$ ( 3 inches) is sufficient to protect winter wheat from winter kill (Peel and Riveland 1977) and thus, the Pst can survive as dormant mycelium as long as infected leaves survive during winter (Sharp and Hehn 1963). In snow areas, snow cover insulates sporulating lesions from the cold temperatures, so air temperatures do not eliminate the pathogen (Zadoks 1961; Burleigh 1965). SI obtained using the 30-day minimum MAT based on daily minimum temperatures [30DMinMAT(Min)] and respective 30-day maximum (30DMax) temperature yielded consistent and plausible SI with known stripe rust epidemic locations.

The 30-day minimum MAT based on the daily minimum temperatures, 30D-MinMAT(Min), was classified into four categories based on effect of temperature and snow cover on Pst survival (Table 2). Burleigh (1965) found that Pst could not survive when 30D-MinMAT(Min) was $-10{ }^{\circ} \mathrm{C}$ in field conditions even in the presence of snow cover. But in the absence of sufficient snow cover, a monthly mean temperature of $-6{ }^{\circ} \mathrm{C}$ or less is enough to kill the pathogen ( $\mathrm{Li}$ and Zeng 2002). Severe cold eliminates green foliage and consequently the stripe rust fungus is also eliminated from the wheat plants. Therefore, in the presence of sufficient snow cover $(>7.6 \mathrm{~cm})$, Pst can survive as a dormant mycelium when 30D-MinMAT(Min) is $>-10^{\circ} \mathrm{C}$ but Pst cannot survive $\leq-6{ }^{\circ} \mathrm{C}$ without snow cover. The rust fungus can survive as dormant mycelium when monthly temperatures are $>$ $-6{ }^{\circ} \mathrm{C}$ regardless of snow cover (Burleigh 1965; Li and Zeng 2002). The temperature range from $\geq-1$ to $11{ }^{\circ} \mathrm{C}$ permits active survival of Pst. Pst can infect plants in $3 \mathrm{~h}$ at $11^{\circ} \mathrm{C}$ under optimum moisture conditions (Burleigh 1965). 
However, different amounts of germination, infection and disease development have been reported within the range of $\geq-1$ to $11^{\circ} \mathrm{C}$ (Naoumova 1937; Zadoks 1961; Burleigh 1965; Dennis 1987b; Line 2002). Burleigh (1965) observed infection below $-4{ }^{\circ} \mathrm{C}$ under field conditions but did not observe infection under laboratory conditions even at $-1.5{ }^{\circ} \mathrm{C}$. Therefore maximum temperature $\leq-5{ }^{\circ} \mathrm{C}$ was considered as the low limit for germination and infection and $\leq-3$ to $-4{ }^{\circ} \mathrm{C}$ as a putative low marginal limit for germination and infection. Similarly, temperatures from $\leq-2$ to $-1{ }^{\circ} \mathrm{C}$ were defined as marginally favorable for infection. The stripe rust fungus could infect host plants near $0{ }^{\circ} \mathrm{C}$ and temperatures from 0 to $1{ }^{\circ} \mathrm{C}$ were defined as moderately favorable for germination and infection (Zadoks 1961; Dennis 1987b). In the presence of dew, germination occurs from $2{ }^{\circ} \mathrm{C}$ to $15{ }^{\circ} \mathrm{C}$, with an optimum at $7{ }^{\circ} \mathrm{C}$ (Rapilly 1979). Temperature from $2{ }^{\circ} \mathrm{C}$ to $11{ }^{\circ} \mathrm{C}$ is favorable for Pst germination and infection, and temperature from $\geq 12{ }^{\circ} \mathrm{C}$ to $30{ }^{\circ} \mathrm{C}$ is favorable for disease development. Adjustment to temperature and RH, DP and rainfall was done as described for summer survival. No adjustment was done based on $\mathrm{DP}$ and rainfall if DP was $<0{ }^{\circ} \mathrm{C}$. If a minimum temperature for 30 -day coldest period was $\geq 12{ }^{\circ} \mathrm{C}$, the SI was calculated as summer SI as described in Table 1.

\section{Model validation}

Survival indices calculated based on Table 1 and Table 2 were validated using observed SI from 20 locations representing Washington, Idaho, Montana, and Texas. Survival indices from 1 to 4 , and 5 to 10 were combined due to the low number of sites with the indices for these locations. The classified three categories were unfavorable $(\mathrm{SI}=0)$, marginal $(\mathrm{SI}=1-4)$ and favorable $(\mathrm{SI}=5-10)$. The goodness of fit was determined using Chi-squared tests.

\section{Spatial interpolation}

Summer and winter SI for each location with their respective geographical coordinates were exported to geographic information system (GIS) software (ArcMap 10; ESRI, Redlands, CA) to interpolate values between weather stations. A deterministic interpolation method inverse distance weighting was used (Theobald 2005). The spatial interpolation was validated separately for oversummering and overwintering indices using 35 locations representing 27 states which were not included in the summer and winter SI calculation. The interpolation was done on an equidistant conical projected US map.

\section{Results}

Most oversummering and overwintering areas of the wheat stripe rust pathogen have different spatial distributions within the contiguous US. Only a few locations overlap and are favorable for both oversummering and overwintering of the pathogen.

\section{Oversummering}

Summer survival of Pst was found either in higher latitudes north of $>40^{\circ} \mathrm{N}$, in northern states, or higher altitudes in southern states (Fig. 1a). At least one location in 23 states, Arizona, California, Colorado, Idaho, Maine, Michigan, Minnesota, Montana, North Carolina, North Dakota, Nebraska, New Hampshire, New Mexico, Nevada, New York, Oregon, Pennsylvania, South Dakota, Tennessee, Utah, Washington, Wisconsin and Wyoming is favorable for summer survival ( $\mathrm{SI} \geq 8$ ). Among these states, the coastal range of Oregon and Washington and the Rocky Mountain range in Idaho, Montana, Wyoming and Colorado were major regions favorable for oversummering. Highlands of the Sierra Nevada in California or the Rocky Mountains in Arizona, New Mexico and Nevada were also favorable for summer survival. Similarly, the high hills of the Appalachian Mountains range in North Carolina and Tennessee favor Pst summer survival. Other favorable locations are in localized areas in the northern states. Moderately and intermediately favorable summer environments $(\mathrm{SI}=\geq 6-7)$ were found in 26 states: Maryland, Virginia, and West Virginia and 23 states listed above for $\mathrm{SI} \geq 8$.

Most areas of southern California, the southern Great Plains and the southeast coastal regions were either marginally favorable or unfavorable for Pst oversummering. At least one marginally suitable area for Pst survival was in Connecticut, Georgia, Iowa, Indiana, Kentucky, Massachusetts, New Jersey, Ohio, Rhode Island, South Carolina and Vermont (maximum $\mathrm{SI}=4$ ). Summer is unfavorable for Pst survival in Arkansas, Delaware, Illinois, Kansas, Missouri, Oklahoma and Texas (maximum $\mathrm{SI}=2$ ); Louisiana (maximum $\mathrm{SI}=1$ ); and Alabama, Florida and Mississippi (SI=0).

\section{Overwintering}

Areas favorable for winter survival (SI $\geq 5$ ) of Pst were found in 14 states: Alabama, Arkansas, Arizona, Florida, Georgia, Louisiana, Mississippi, New Mexico, Nevada, South Carolina, Texas, California, Oregon and Washington (Fig. 1b). These states are either in south of $40^{\circ} \mathrm{N}$ or in the Pacific Rim. All of these states except New Mexico had favorable or more favorable ( $\mathrm{SI} \geq 8$ ) overwintering locations. 
Fig 1 Potential oversummering (a), overwintering (b) and oversummering and overwintering (c) survival regions of the wheat stripe rust pathogen, Puccinia striiformis f. sp. tritici, in the contiguous United States. Wheat cultivating counties are for spring and winter wheat shown in $\mathbf{a}$ and $\mathbf{c}$, and for winter wheat only in $\mathbf{b}$

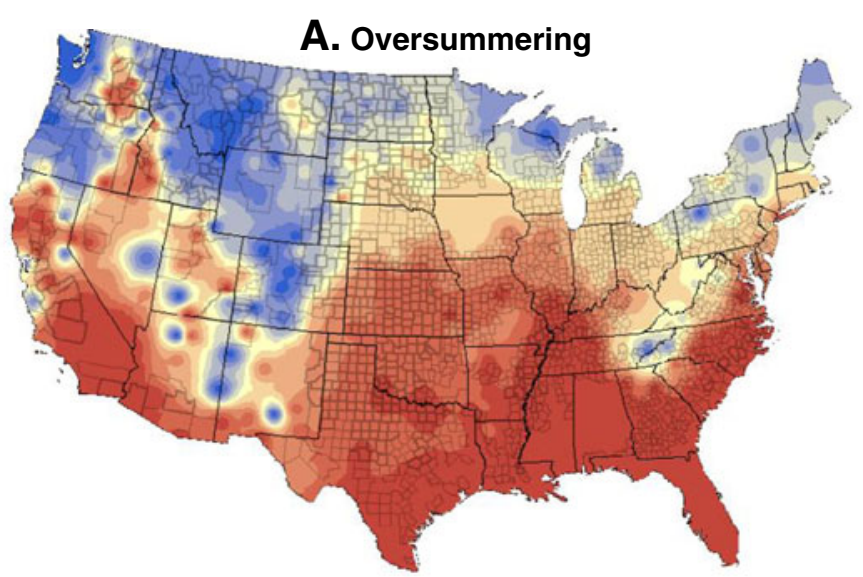

B. Overwintering

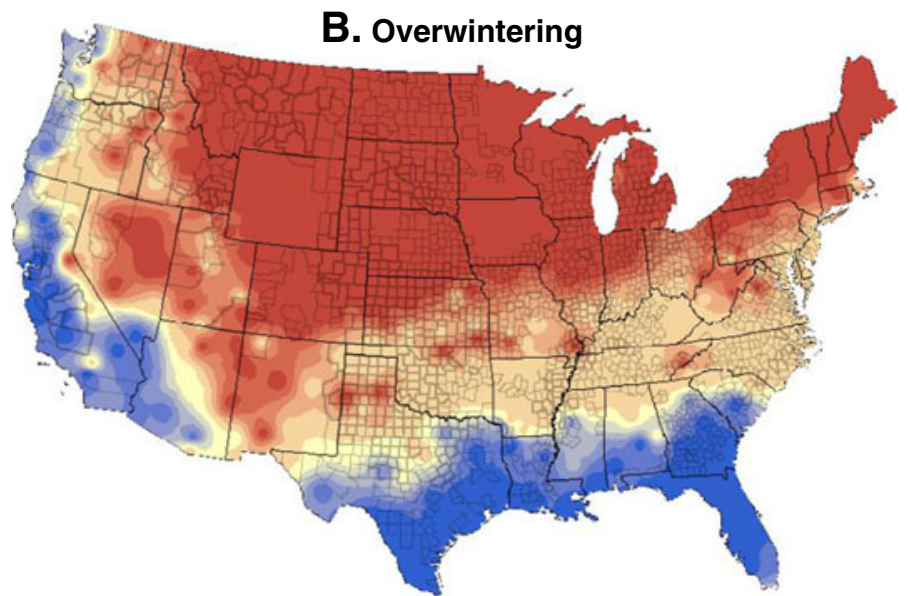

C. Oversummering and overwintering

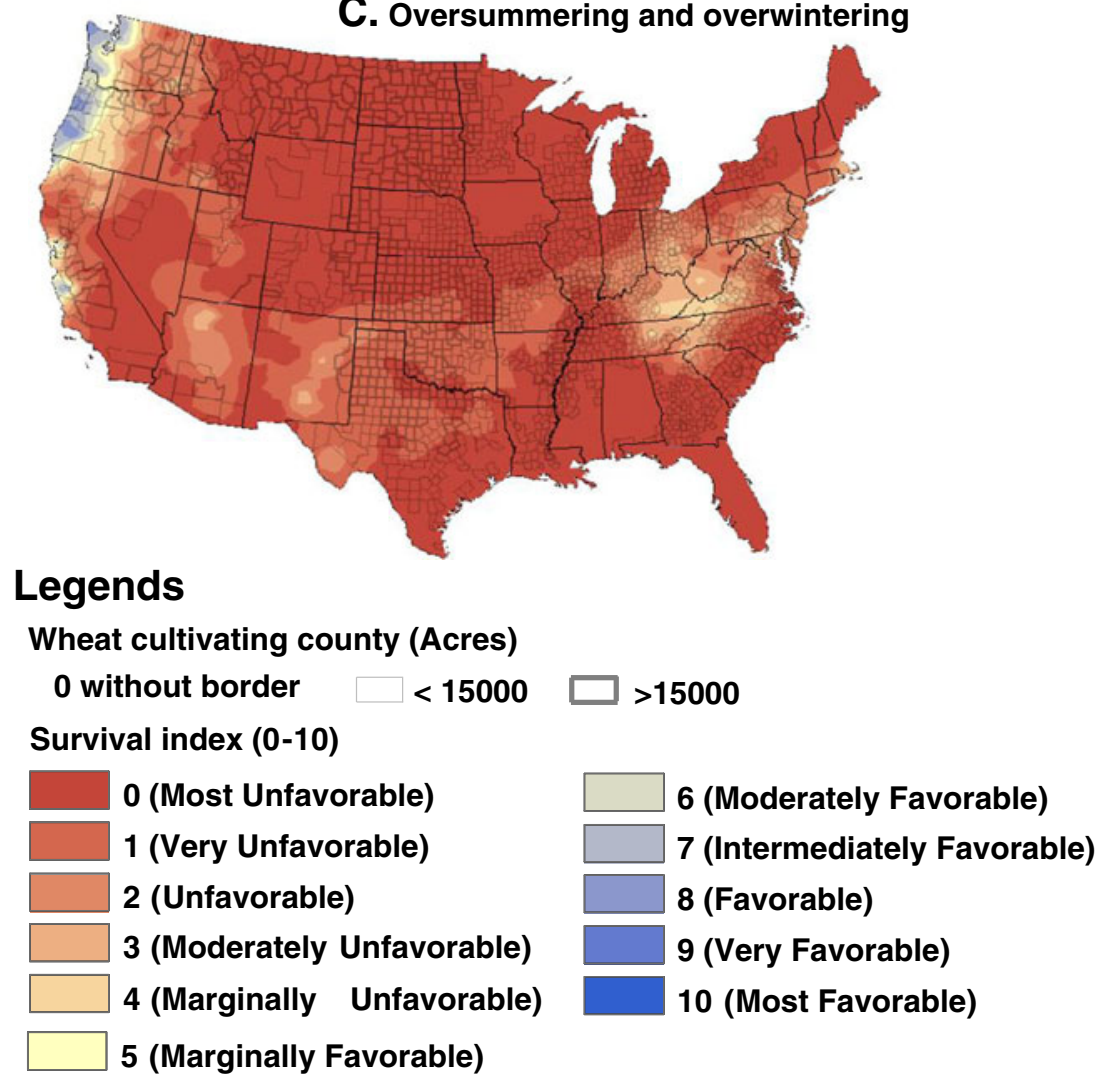




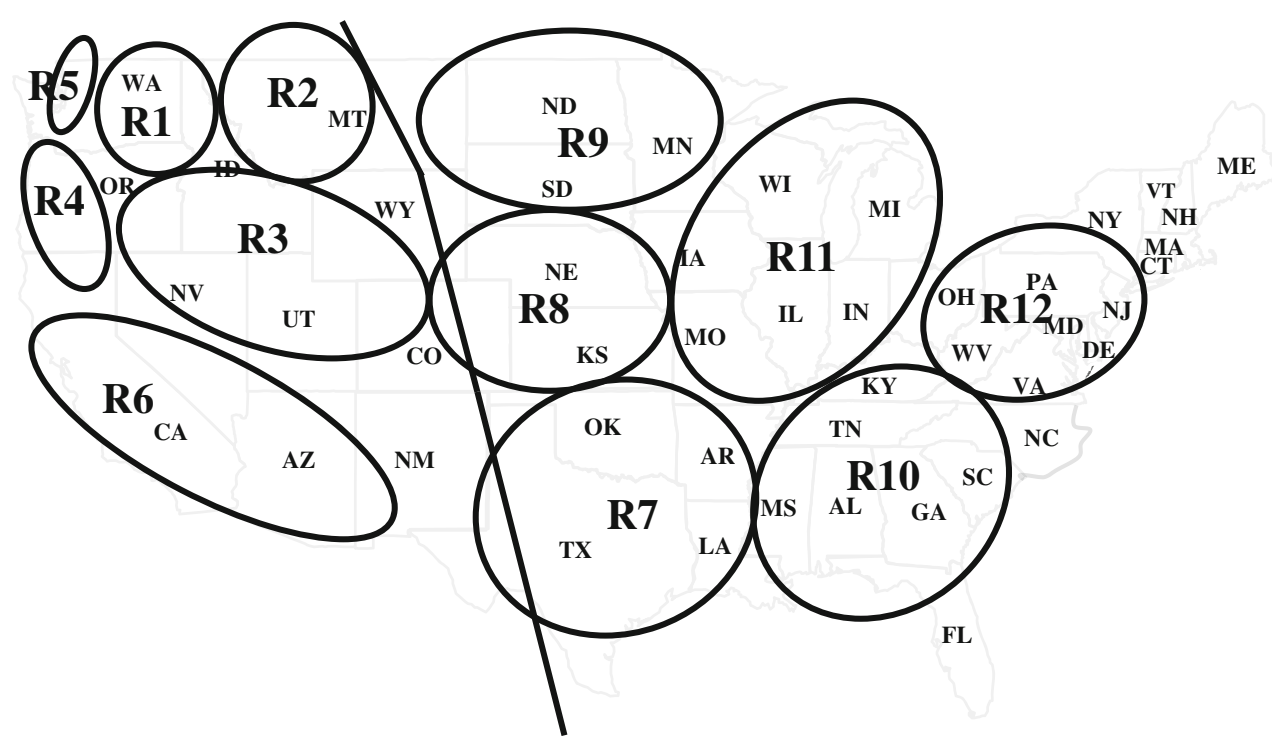

Fig 2 Epidemiological regions of wheat stripe rust, caused by Puccinia striiformis f. sp. tritici, in the United States. Region 1 $(R I)=$ eastern Washington, northeastern Oregon and northern Idaho; $R 2=$ western Montana; $R 3=$ southern Idaho, southeastern Oregon, northern Nevada, northern Utah, western Wyoming and western Colorado; $R 4=$ western Oregon and northern California; $R 5=$ northwestern Washington; $R 6=$ central and southern California, Arizona and western New Mexico; $R 7=$ Texas, Louisiana, Arkansas,
Oklahoma and eastern New Mexico; $R 8=$ Kansas, Nebraska and eastern Colorado; $R 9=$ South Dakota, North Dakota, Minnesota and eastern Montana; $R 10=$ Mississippi, Alabama, Florida, Georgia, South Dakota, North Dakota, Tennessee and Kentucky; R11=Missouri, Illinois, Indiana, Iowa, Wisconsin and Michigan; R12=Virginia, West Virginia, Ohio, Maryland, Pennsylvania and New York [see Line and Qayoum (1992) and Chen et al. (2010) for details, the figure is adapted from Chen et al. (2010)]
Moderately and intermediately favorable winter survival locations ( $\mathrm{SI}=\geq 6-7$ ) were found in 13 states (Fig. 1b).

In general, Pst cannot overwinter in most regions north of $40^{\circ} \mathrm{N}$ in states east of the Rocky Mountains. The fungus can survive marginally during winter (maximum $\mathrm{SI}=4$ ) in Delaware, Idaho, Illinois, Indiana, Kansas, Kentucky, Massachusetts, Maryland, Missouri, North Carolina, New Jersey, New York, Ohio, Oklahoma, Pennsylvania, Rhode Island, Tennessee, Utah, Virginia and West Virginia. Overwintering is unfavorable in Michigan (maximum $\mathrm{SI}=1)$ and most unfavorable in Colorado, Connecticut, Iowa, Maine, Minnesota, Montana, North Dakota, Nebraska, New Hampshire, South Dakota, Vermont, Wisconsin and Wyoming (maximum $\mathrm{SI}=0$ ).

\section{Oversummering and overwintering}

Most areas of the US are not suitable for Pst survival in both summer and winter (Fig. 1c). Only the Pacific Rim states (California, Oregon and Washington) have areas favorable for survival in summer and winter seasons (minimum SI $\geq 8$ ). The pathogen can marginally survive both summer and winter in Arizona, Georgia, Kentucky, Massachusetts, North Carolina, New Jersey, New Mexico, Ohio, Pennsylvania, Rhode Island, South Carolina, Tennessee, Virginia and West Virginia (minimum $\mathrm{SI}=4$ ); and Idaho (except areas bordering Washington), Indiana, and Utah (minimum $\mathrm{SI}=3$ ). Oversummering and overwintering are unfavorable in Arkansas, Delaware, Illinois, Maryland, Missouri, Nevada, Oklahoma and Texas (minimum SI=2); and Kansas, Louisiana and Michigan (minimum $\mathrm{SI}=1$ ). Both oversummering and overwintering were most unfavorable (minimum $\mathrm{SI}=0$ ) in Alabama, Colorado, Connecticut, Florida, Iowa, Maine, Minnesota, Mississippi, Montana, North Dakota, Nebraska, New Hampshire, New York, South Dakota, Vermont, Wisconsin and Wyoming.

\section{Model validation}

Frequencies of SI between calculated SI and field data did not differ significantly for both summer $\left(\chi^{2}=4.08, \mathrm{df}=2\right.$, $P=0.05)$ and winter $\left(\chi^{2}=1.06, \mathrm{df}=2, P=0.05\right)$ survival. Observed SI values were estimated based on the stripe rust appearance during summer, fall, and winter season from the local source of inoculum. Therefore these estimated SI was considered as observed SI and should be representative of experimental condition under field conditions. Agreement on frequencies between field observations and predicted SI further strengthened validation of the model. Thirty-five locations used for spatial interpolation validation were from 27 states. Observed and expected frequencies SI did not differ significantly for summer $\left(\chi^{2}=5.27, \mathrm{df}=2, P=0.05\right)$ and winter $\left(\chi^{2}=1.05\right.$, $\mathrm{df}=2, P=0.05)$. 


\section{Discussion}

The contiguous US has spatial variability for oversummering and overwintering survival of the stripe rust pathogen. Most wheat-growing regions are either favorable for oversummering or overwintering of the pathogen but not suitable for both oversummering and overwintering. Both summer and winter survival regions are located mostly in the Pacific coastal areas and the Appalachian Mountains range. Favorable environments in the highlands of southern states suggest that the pathogen can oversummer and overwinter in those areas too. The survival potentials of Pst during summer and winter were different among the previously defined stripe rust regions in the US (Fig. 2) (Line and Qayoum 1992; Chen et al. 2010). Most of the northern wheat-growing states have mostly favorable [Stripe rust epidemiological region 1 (R1), R2, R3, R4, and R5] or at least a marginally favorable (R9, R11 and R12) environment for summer survival of the pathogen. This is because temperature is not a limiting factor for Pst survival in these regions. Since wheat is ready to harvest during JulySeptember, the pathogen needs to rely on early volunteers and/or other grass hosts for summer survival in some of the regions.

Oversummering inoculum can serve as local or endogenous sources, causing fall infection in winter wheat. However, the cultivation of winter wheat is not as common in the northern Great Plains compared to southern states. Therefore, inoculum originating from summer survival in the low density winter wheat cultivating states may not play as an important role in disease initiation as intensive winter wheat cultivation states. Furthermore, high humidity in the Great Plains may not be favorable for urediniospore survival during summer (Chen 2005). Therefore, the oversummering of Pst is less likely in Midwestern states than in the Pacific Northwest states. One of the important findings of the present study is that Pst can oversummer in the highlands of the Rocky Mountains in southern states (Arizona, Colorado, New Mexico, Nevada and Utah) (R3, R6 and R7) and the Appalachian Mountains (North Carolina, Tennessee Virginia and West Virginia) (R10 and R12). Oversummering of Pst in these areas may provide inoculum for late fall or winter infection for those regions. In addition, many mountains in southern states such as Guadalupe Peak $\left(2,667 \mathrm{~m}\right.$, ca. $\left.31^{\circ} \mathrm{N}\right)$, Texas, were not included in the study due to the lack of sufficient weather data or weather stations in these locations. These mountains are either further north, higher in altitude (http://geology.com/state-high-points.shtml) or both than the Sequoia National Park Mountains in California $\left(1,828 \mathrm{~m}\right.$, ca. $\left.36^{\circ} \mathrm{N}\right)$, Himalaya $(\geq 1,600 \mathrm{~m}$, ca. 28 $\left.29^{\circ} \mathrm{N}\right)$ in Asia and Nilgiri hills in India $\left(2,500 \mathrm{~m}, \mathrm{ca} .11^{\circ} \mathrm{N}\right)$, where oversummering of Pst has been reported consistently (Tollenaar and Houston 1967; Stubbs 1985). Therefore, the pathogen is very likely to survive during both summer and winter seasons in these mountainous regions. Climatic suitability of some areas in the Appalachian Mountains range for Pst survival may provide inoculum on either side of the mountain range. This may explain the appearance of stripe rust in Virginia similar to or earlier than in southern states, Colorado, Kansas and Nebraska, close to Texas (Chen et al. 2010). Thus, reestablishment of the fungus in Alabama, Mississippi, Georgia and Florida may also be result of urediniospores carried by winds from the Appalachian Mountains.

Climatic suitability for overwintering of Pst in the Pacific West (R1, R2, R4, R5, and R6) is in agreement with previous field studies conducted in these regions (Tollenaar and Houston 1967; Tu 1967; Shaner and Powelson 1973; Line 2002; Chen 2005). Early sown wheat infected during the previous fall may provide the primary inoculum for disease epidemics in the spring ( $\mathrm{Tu}$ 1967; Line 2002). A similar phenomenon for stripe rust development may occur in other overwintering regions of the US. Pst cannot overwinter due to the low temperatures in the major winter-wheat-growing areas in the regions east of the Rocky Mountains and in the northern Great Plains. However, Pst may overwinter as long as the infected foliage remain green during winter. Pst can overwinter in those regions where overwintering of leaf rust fungus ( $P$. triticina) have been reported as in central Nebraska (Eversmeyer and Kramer 1996). Therefore, in the regions north of Nebraska, stripe rust can initiate in the spring mostly from the exogenous sources of inoculum where the pathogen can overwinter from fall infections. The Rocky Mountains generally provide a barrier for wind movement from the oversummering and overwintering regions west of the Rocky Mountains. Therefore, the overwintering inocula originating in the southern states are very likely causes of stripe rust in the northern Great Plains during the spring (Chen 2005). The Appalachian Mountains areas with climatic suitability for Pst overwintering may be a potential source of inoculum for surrounding states.

The most favorable year-round climatic conditions for both summer and winter survival were found in northwestern Washington (R5), western Oregon and northern California (R4), and a few locations in central and southern California, Arizona and western New Mexico (R6). Most of these regions have mild winters and cool summers favorable for the year-round survival of the pathogen. Urediniospores can be detected most of the year, especially west of the Cascade Mountains. Regions east of the Cascade Mountains in eastern Washington often have survival of the pathogen as dry urediniospores in summer (Tu 1967) or dormant mycelium during winter season (Burleigh 1965). The disease can be initiated by indigenous inoculum and provide inoculum for those regions where the pathogen cannot survive in either one or both summer and winter seasons. The identified oversummering and overwintering regions match with the 
most vulnerable and historically important stripe rust epidemic regions, the PNW and California (Chen 2005) and western mountain ranges of the US. In addition, the large number of races and first reports of new races often occur in the PNW and California, where the pathogen can oversummer and overwinter (Chen et al. 2010). Therefore, the oversummering and overwintering regions can be considered as hot spot areas of stripe rust. Similarly in China, year-round survival areas such as southern Gansu, northwestern Sichuan and Yunnan are considered stripe rust hot spots since these regions were associated with evolution of new races and high pathogenic variability (Li and Zeng 2002). Considering the high virulence diversity, screening of wheat breeding lines for resistance has been done in Mt. Vernon (R5) and Pullman (R1), Washington in the US.

The stripe rust pathogen could not survive either in summer or winter in most of the Great Plains states, northeastern states and southeastern states, except in highlands. The pathogen may survive in the Appalachian Mountains range spreading from Georgia (R10) to Pennsylvania (R12). These areas may favor the survival of Pst during both summer and winter as in the Pacific Northwest and California where the pathogen can survive year around, and provide inoculum to the surroundings regions. Similarly, in a mild summer, the northwestern part of Texas and Oklahoma (R7) may have dormant stripe rust inoculum. States in Region 2 (western Montana), Region 8 (Kansas, Nebraska and eastern Colorado), Region 9 (South Dakota, North Dakota, Minnesota and eastern Montana), Region 10 (Mississippi, Alabama, Florida, Georgia, South Dakota, Tennessee and Kentucky) and Region 11 (Missouri, Illinois, Indiana, Iowa, Wisconsin, and Michigan) are unfavorable for summer and/or winter survival and mostly rely on exogenous sources of inoculum to initiate the disease.

Spatially isolated Pst survival regions can be bridged by windborne long distance dispersal of urediniospores resulting large epidemic regions (Zadoks 1961, 1965; Wang et al. 2010). Dispersal of Pst from oversummering and/or overwintering areas into an area where it cannot survive from year to year has been reported in North America (Mexico, the US and Canada) as the Puccinia pathway (Stakman 1934) and also in China (Wang et al. 2010). Wind directions and speed are variable during different seasons in the US (http:// hurricane.ncdc.noaa.gov/cgi-bin/climaps/climaps.pl). For example, in general southerly winds prevail during March and April in southern states and Mexico where Pst can overwinter. Urediniospores may dispersal further north from these states and ultimately reach northern wheat growing states and Canada. Stripe rust was reported from January to April in overwintering regions in Texas and reached to nonoverwintering north states (e.g. South Dakota and North Dakota) in June to July (Chen et al. 2010). Although there is no field evidence of oversummering of $P s t$ in New Mexico and the Guadalupe Peak, Texas, based on the climatic suitability, Pst can survive during summer and have potential of dispersal in north, northwest, and south during October to December. These regions may provide inoculum to the major wheat growing areas of Texas, where the Pst cannot oversummer. Wide distribution (http://plants.usda.gov) of grass hosts (Hungerford 1923; Hendrix et al. 1965; Dietz and Hendrix 1962; Tu 1967) in Pst potential survival areas can cause local and regional epidemics from urediniospores originating in grass hosts (Hungerford 1923; Hungerford and Owens 1923; Hendrix et al. 1965; Brown and Hovmøller 2002). Periodic infections are not necessary in perennial hosts, which can remain green in summer and winter. Role of these hosts would be particularly important on the southern states mountains or highlands.

\section{Conclusions}

In general, potential oversummering areas for $P s t$ are the northern states and highlands of southern states whereas the Pacific coast and southern states favor overwintering. The pathogen cannot survive in most of the wheat growing areas in both summer and winter seasons. Therefore, stripe rust epidemics in these regions depend on exogenous inoculum. Oversummering and overwintering regions are the historically important stripe rust epidemic regions, California and the Pacific Northwest. Other areas for potential summer and winter survival are the highlands of Arizona and the Appalachian Mountains range. Oversummered and overwintered Pst may produce disease foci under conducive weather conditions, cause an epidemic as the season progresses, and provide inoculum for other regions. Further studies on the role of these survival areas will help to understand regional and interregional epidemiology of stripe rust in the US.

Acknowledgments This research was supported by the US Department of Agriculture, Agricultural Research Service (Project No. 5348-22000-014-00D) and Washington State University (Project No. 13C-3061-3925 and 13C-3061-3232) PPNS No. 0580, Department of Plant Pathology, College of Agricultural, Human, and Natural Resource Sciences, Agricultural Research Center, Project Number WNP00663, Washington State University, Pullman, WA 99164-6430, USA. We would like to thank Drs. D. A. Johnson and T. D. Murray for critical review of the manuscript.

\section{References}

Brouwer C, Heibloem M (1986) Irrigation water management: Irrigation water needs, irrigation water management training manual No. 3. http://www.fao.org/docrep/S2022E/s2022e06.htm. Accessed 18 December 2010 
Brown JKM, Hovmøller MS (2002) Aerial dispersal of pathogens on the global and continental scales and its impact on plant disease. Science 297:537-541

Burleigh JR (1965) The winter biology of Puccinia striiformis West. in the Pacific Northwest. Dissertation, Washington State University

Chen XM (2005) Epidemiology and control of stripe rust [Puccinia striiformis f. sp. tritici] on wheat. Can J Plant Pathol 27:314-337

Chen XM, Penman L, Wan AM, Cheng P (2010) Virulence races of Puccinia striiformis f. sp. tritici in 2006 and 2007 and development of wheat stripe rust and distributions, dynamics, and evolutionary relationships of races from 2000 to 2007 in the United States. Can J Plant Pathol 35:315-333

de Vallavieille-Pope C, Huber L, Leconte M, Goyeau H (1995) Comparative effects of temperature and interrupted wet periods on germination, penetration, and infection of Puccinia recondita f. sp. tritici and $P$. striiformis on wheat seedlings. Phytopathology 85:409-415

Dennis JI (1987a) Effect of high temperatures on survival and development of Puccinia striiformis on wheat. Trans Br Mycol Soc 88:91-96

Dennis JI (1987b) Temperature and wet-period conditions for infection by Puccinia striiformis $\mathrm{f}$. sp. tritici race 104E137A +. Trans $\mathrm{Br}$ Mycol Soc 88:119-121

Dennis J, Brown J (1986) Summer survival of Puccinia striiformis f. sp tritici in Victoria, Australia. Aust Plant Pathol 15:57-60

Dietz SM, Hendrix JW (1962) Reaction of grasses to stripe rust at Pullman, Washington. Phytopathology 52:730

Doodson KJ, Manners JG, Myers A (1964) Some effects of yellow rust (Puccinia striiformis) on the growth and yield of spring wheat. Ann Bot 28:459-472

Ellison PJ, Murray GM (1992) Epidemiology of Puccinia striiformis f. sp. tritici on wheat in southern New South Wales. Aust J Agric Res 43:29-41

Eversmeyer MG, Kramer CL (1996) Modeling winter wheat and early spring survival of Puccinia recondita in wheat nurseries during 1980 to 1993. Plant Dis 80:490-493

Georgievskaja NA (1966) Quelques lois sur Ie developpement de la rouille Jaune du ble. Tr. Vses. Nauchno Issled. Inst Zabtsh Rost Leningrad 26:55-63

Hassebrauk K (1965) Nomenklatur, geographische Verbreitung und wirtsbereich des Gelbrostes, Puccinia striiformis West. Mitt Biol Bundesanst Land Forstwirtsch 116:1-75

Hendrix JW, Burleigh JR, Tu JC (1965) Oversummering of stripe rust at high elevations in the Pacific Northwest-1963. Plant Dis Rep 49:275-78

Hong TD, Ellis RH, Moore D (1997) Development of a model to predict the effect of temperature and moisture on fungal spore longevity. Ann Bot 79:121-128

Hungerford CW (1923) Studies on the life history of stripe rust, Puccinia glumarum. J Agric Res 24:607-20

Hungerford CW, Owens CE (1923) Specialized varieties of Puccinia glumarum and hosts for variety tritici. J Agric Res 25:363-401

Imbaby IA, Nazim M, Ali MM, Abdel-Malek NI (2005) Viability of wheat rust urediniospores produced on different stages of susceptible plants. Egypt J Phytopathol 33:59-76

Kang Z, Zhao J, Han D, Zhang H, Wang X, Wang C, Han Q, Guo J, Huang L (2010) Status of wheat rust research and control in China. BGRI 2010 Technical Workshop, May 30-31 2010, St Petersburg, Russia. http://www.globalrust.org/db/attachments/bgriiwc/24/2/07kang-ca-A4-embargo.pdf. Accessed 14 December 2010

Li ZQ, Zeng SM (2002) Wheat rusts in China. China Agricultural, Beijing

Line RF (2002) Stripe rust of wheat and barley in North America: a retrospective historical review. Annu Rev Phytopathol 40:75-118

Line RF, Qayoum A (1992) Virulence, aggressiveness, evolution, and distribution of races of Puccinia striiformis (the cause of stripe rust of wheat) in North America, 1968-87. Technical Bulletin
Number 1788. United States Department of Agriculture, Agricultural Research Service

Ma ZH, Shi SD, Jiang YY, Zhao ZH (2005) Climate-based regional classification for oversummering of Puccinia striiformis in China with GIS. Acta Phytopathol Sin 34:455-462

Maddison AC, Manners JG (1973) Lethal effects of artificial ultraviolet radiation on cereal rust uredospores. Trans Br Mycol Soc 60:471-494

McCracken FI, Burleigh JR (1962) Influence of light and temperature on in vitro germination of Puccinia striiformis uredospores. Phytopathology 52:742

Murray GM, Ellison PJ, Watson A, Cullis BR (1994) The relationship between wheat yield and stripe rust as affected by length of epidemic and temperature at the grain development stage of crop growth. Plant Pathol 43:397-405

Naoumova NAM (1937) Natural fluctuations of temperature and the duration of the incubation period of Puccinia glumarum f. sp. tritici. Zaschita Rasteniy 12:51-66

Peel MD, Riveland N (1977) Winter wheat production in North Dakota. Extension bulletin 33. http://www.ag.ndsu.edu/pubs/ plantsci/smgrains/eb33w.htm. Accessed 5 May 2011

Rapilly F (1979) Yellow rust epidemiology. Annu Rev Phytopathol 17:59-73

Shaner G, Powelson RL (1971) Epidemiology of stripe rust of wheat, 1961-1968. Oreg Agric Exp Stn Tech Bull 117

Shaner G, Powelson RL (1973) The oversummering and dispersal of inoculum of Puccinia striiformis in Oregon. Phytopathology 63:13-17

Sharma-Poudyal D, Chen XM (2011) Models for predicting potential yield loss of wheat caused by stripe rust in the US Pacific Northwest. Phytopathology 101:544-554

Sharp EL (1965) Prepenetration and postpenetration environment and development of Puccinia striiformis on wheat. Phytopathology 55:198-203

Sharp EL, Hehn ER (1963) Overwintering of stripe rust in winter wheat in Montana. Phytopathology 53:1239-40

Shi SD, Ma ZH (2005) Climate-based regional classification for overwintering of Puccinia striiformis in China with GIS and geostatistics. ACTA Phytophylacica Sinica 32:29-32

Smilanick JL, Mansour MF (2007) Influence of temperature and humidity on survival of Penicillium digitatum and Geotrichum citriaurantii. Plant Dis 91:990-996

Stakman EC (1934) Epidemiology of cereal rusts. Proceedings of the Fifth Pacific ScienceCongress (Canada), 1933, vol 4, University of TorontoPress, Toronto, pp 3177-3184

Stubbs RW (1985) Stripe rust. In: Roelfs AP, Bushnell WR (eds) The cereal rusts, vol II. Diseases, distribution, epidemiology, and control. Academic, Florida, pp 61-101

Sutton JC (1988) Predictive value of weather variables in the epidemiology and management of foliar diseases. Fitopatol Bras 13:305-12

Theobald DM (2005) GIS concepts and ArcGIS methods, 2nd edn. Conservation Planning Technologies, Fort Collins

Tollenaar H, Houston BR (1966) Effect of temperature during uredospore production and light on in vitro germination of urediniospores of Puccinia striiformis. Phytopathology 56:787-790

Tollenaar H, Houston BR (1967) A study on the epidemiology of stripe rust, Puccinia striiformis West., in California. Can J Bot 45:291-307

Tu JC (1967) The summer biology of Puccinia striiformis West. In Southeastern Washington. Dissertation, Washington State University

Wang H, Yang XB, Ma Z (2010) Long-distance spore transport of wheat stripe rust pathogen from Sichuan, Yunnan, and Guizhou in southwestern China. Plant Dis 94:873-880

Zadoks JC (1961) Yellow rust on wheat, studies in epidemiology and physiologic specialization. Neth J Plant Pathol 67:69-256

Zadoks JC (1965) Epidemiology of wheat rust in Europe. FAO Plant Prot Bull 13:97-108 